\title{
Hubungan Derajat Proteinuria, Kadar albumin, dan Kolesterol Serum dengan Kadar Zinc pada Anak sindrom Nefrotik (Kajian saat serangan dan remisi)
}

Muhammad Fathah, Muhammad Heru Muryawan

Departemen Ilmu Kesehatan Anak Fakultas Kedokteran/Universitas Diponegoro / RSUP Dr. Kariadi Semarang

Latar belakang. Gangguan glomerular filtration complex (GFC) pada anak sindrom nefrotik (SN), yang digambarkan dengan derajat proteinuria, meloloskan berbagai komponen serum melalui urin termasuk zinc. Albumin yang merupakan transporter zinc, menurun pada SN.

Tujuan. Mengetahui hubungan derajat proteinuria, kadar albumin, dan kolesterol serum dengan kadar zinc pada anak SN saat serangan dan saat remisi.

Metode. Penelitian cross sectional pada 25 anak SN saat serangan dan 30 anak SN saat remisi. Subjek diperiksa derajat proteinuria, kadar albumin, kolesterol total, dan zinc serum.

Hasil. Derajat proteinuria anak SN saat serangan paling banyak +3 (44\%), saat remisi 0 (86,7\%). Derajat proteinuria saat serangan berhubungan secara bermakna dengan kadar zinc serum $(\mathrm{p}=0,044)$. Kadar albumin dan kolesterol serum tidak berkorelasi secara bermakna dengan kadar zinc serum pada saat serangan maupun remisi.

Kesimpulan. Rerata kadar zinc anak SN saat serangan lebih rendah dibandingkan saat remisi. Kadar zinc yang rendah berhubungan dengan semakin beratnya derajat proteinuria saat serangan. Kadar albumin dan kolesterol serum tidak berkorelasi dengan kadar zinc serum pada anak SN saat serangan maupun remisi. Sari Pediatri 2022;23(5):285-9

Kata kunci: sindrom nefrotik, proteinuria, albumin, kolesterol, zinc, anak

\section{Relationship of Proteinuria, Albumin, and Cholesterol Levels with Zinc in Childhood Nephrotic Syndrome (Study on attack and remission)}

Muhammad Fathah, Muhammad Heru Muryawan

Background. Impaired glomerular filtration complex (GFC) in childhood nephrotic syndrome (NS), marked by proteinuria degree, losses varying serum components including zinc. Albumin, as the main transporter of zinc, is decreased in NS.

Objective. To acknowledge the relationship of proteinuria, albumin, and cholesterol levels with zinc in childhood NS on attack and remission. Methods. A cross-sectional study among 25 childhood NS during attack and 30 during remission. Data on proteinuria degree, albumin, total cholesterol, and zinc levels were obtained.

Results. Proteinuria degree was predominantly $+3(44 \%)$ during attack and $0(86.7 \%)$ during remission. Proteinuria degree during attack was significantly related to zinc level $(\mathrm{p}=0.044)$. Mean serum albumin and cholesterol levels did not significantly correlate with mean serum zinc level either during attack or remission.

Conclusions. Mean serum zinc level in childhood NS during attack was lower as compared to remission. Lower zinc level was related to higher degree of proteinuria. Serum albumin and cholesterol levels did not correlate with zinc levels in childhood NS either during attack or remission. Sari Pediatri 2022;23(5):285-9

Keywords: nephrotic syndrome, proteinuria, albumin, cholesterol, zinc, childhood

Alamat korespondensi: Muhammad Heru Muryawan. Departemen Ilmu Kesehatan Anak Fakultas Kedokteran/Universitas Diponegoro / RSUP Dr. Kariadi. Jl. Dr. Soetomo No. 16-18, Semarang. Email: heruboja@gmail.com 
$\mathrm{K}$ ompleks filtrasi glomerulus yang rusak pada anak dengan SN meloloskan imunoglobulin, protein, dan trace element zinc yang tahan tub penting untuk pertumbuhan, perbaikan sel, sebagai anti inflamasi dan antioksidan, menjaga struktur, dan fungsi protein serta asam nukleat pada lebih dari 300 enzim dan 2000 faktor transkripsi. Zinc dapat mengurangi kejadian infeksi, terutama saluran pernafasan dan pencernaan. Kekurangan zinc menurunkan ekspresi sel Th-1 yang menyebabkan anak rentan infeksi. ${ }^{4-6}$

Studi menunjukkan bahwa kejadian SN pada anak, baik itu serangan pertama meupun relaps, sebagian besar (50-70\%), didahului infeksi saluran pernafasan dan pencernaan. ${ }^{1,2,6,7}$ Pemberian Zinc memperbaiki defek sistem kekebalan, mengurangi infeksi, dan kekambuhan anak SN. Pemberian zinc pada SN menginduksi remisi lebih cepat, mempertahankan remisi dan mengurangi lama perawatan..$^{8-12}$

Kadar zinc menurun saat relaps dan meningkat kembali saat remisi pada anak SN. ${ }^{12,13}$ Zinc yang rendah pada SN relaps mungkin terkait dengan kadar albumin yang rendah akibat proteinuria yang merupakan transport utama di dalam sirkulasi. ${ }^{2,14,15}$ Defisiensi zinc memengaruhi metabolisme lipid dan meningkatkan kadar kolesterol total. ${ }^{16,17}$

Tujuan penelitian ini adalah untuk mengetahui hubungan derajat proteinuria, kadar albumin, dan kolesterol serum, dengan kadar zinc anak SN saat serangan dan remisi.

\section{Metode}

Penelitian dengan desain cross sectional, telah dilaksanakan pada bulan Mei 2020 - Agustus 2021 terhadap pasien dengan diagnosis $\mathrm{SN}$, baik serangan mapun remisi, usia 1-18 tahun yang datang ke poliklinik dan perawatan bangsal Nefrologi Anak RSUP Dr. Kariadi Semarang. Kriteria eksklusi di antaranya subjek dengan status gizi tidak baik (gizi kurang, gizi buruk, gizi lebih) atau dengan SN sekunder karena penyakit sistemik (nefritis lupus, HSP), infeksi sekunder (malaria skistosomiasis, HBV, HCV, HIV), keganasan (karsinoma paru, karsinoma saluran cerna, limfoma), dan obat-obatan (kaptopril, NSAID, penisilamin, merkuri, lithium, fenitoin).
Derajat proteinuria, melalui urinalisis, dikatagorikan menjadi $0,+1,+2,+3$, dan +4 . Kadar albumin, kolesterol, dan zinc serum didapat dari pemeriksaan darah. Kadar zinc diperiksa di laboratorium GAKY FK UNDIP Semarang dengan perangkat spektrofotometer Atomic Absorbtion spechtrometer (AAS). Status SN serangan dan remisi berdasarkan pedoman IDAI mengenai diagnosis dan tatalaksana sindrom nefrotik anak. Pasien dilakukan anamnesis dan pemeriksaan fisik, antropometri dan didukung pemeriksaan penunjang untuk mengidentifikasi tanda infeksi, status gizi, dan riwayat alergi.

Analisis dilakukan dengan perangkat lunak SPSS. Hubungan derajat proteinuria dengan kadar zinc serum dianalisis dengan uji Kruskal-Wallis karena distribusi data tidak normal. Korelasi kadar albumin serum dengan kadar zinc serum dianalisis menggunkaan uji korelasi Spearman karena distribusi data tidak normal. Korelasi kadar kolesterol total dan zinc serum dianalisis dengan uji korelasi Pearson.

Etichal clearance didapat dari KEPK FK UNDIP No.624/EC/KEPK-RSDK/2019 dan surat ijin penelitian dari RSUP dr Kariadi nomor DP.02.01/I. II/7124/2020.

\section{Hasil}

Penelitian selama 15 bulan mendapatkan 103 anak dengan diagnosis sindrom nefrotik. Terdapat 24 anak menolak menjadi subjek penelitian dan 20 subjek data tidak lengkap. Empat subjek dieksklusi karena memilik status gizi tidak baik. Penelitian dilanjutkan pada 55 subjek pasien SN yang terdiri atas $25 \mathrm{SN}$ saat serangan, dan 30 SN saat remisi.

Rerata usia subjek penelitian pada SN serangan $91,24 \pm 63,26$ bulan sedangkan SN remisi 109,63 \pm 50,43 bulan. Jenis kelamin laki - laki mendominasi, baik pada SN serangan $64 \%$ dan remisi $83,3 \%$. Riwayat alergi pada SN serangan $24 \%$ dan remisi $20 \%$. Proporsi status infeksi aktif pada SN serangan $80 \%$ sedangkan remisi $20 \%$. Proteinuria paling banyak pada SN serangan adalah derajat $+3(44 \%)$, disusul $+4(36 \%)$, dan $+2(20 \%)$. Proteinuria 0 mendominasi SN remisi $(86,7 \%)$ dan hanya 4 subjek $(13,3 \%)$ proteinuria +1 pada SN remisi.

Rerata kadar albumin SN serangan 2,23 $\pm 0,72 \mathrm{mg} /$ $\mathrm{dL}$, lebih rendah dibandingkan SN remisi 4,26 $\pm 0,58$ 
Muhammad Fathah dkk: Hubungan derajat proteinuria, kadar albumin, dan kolesterol serum dengan kadar zinc pada SN

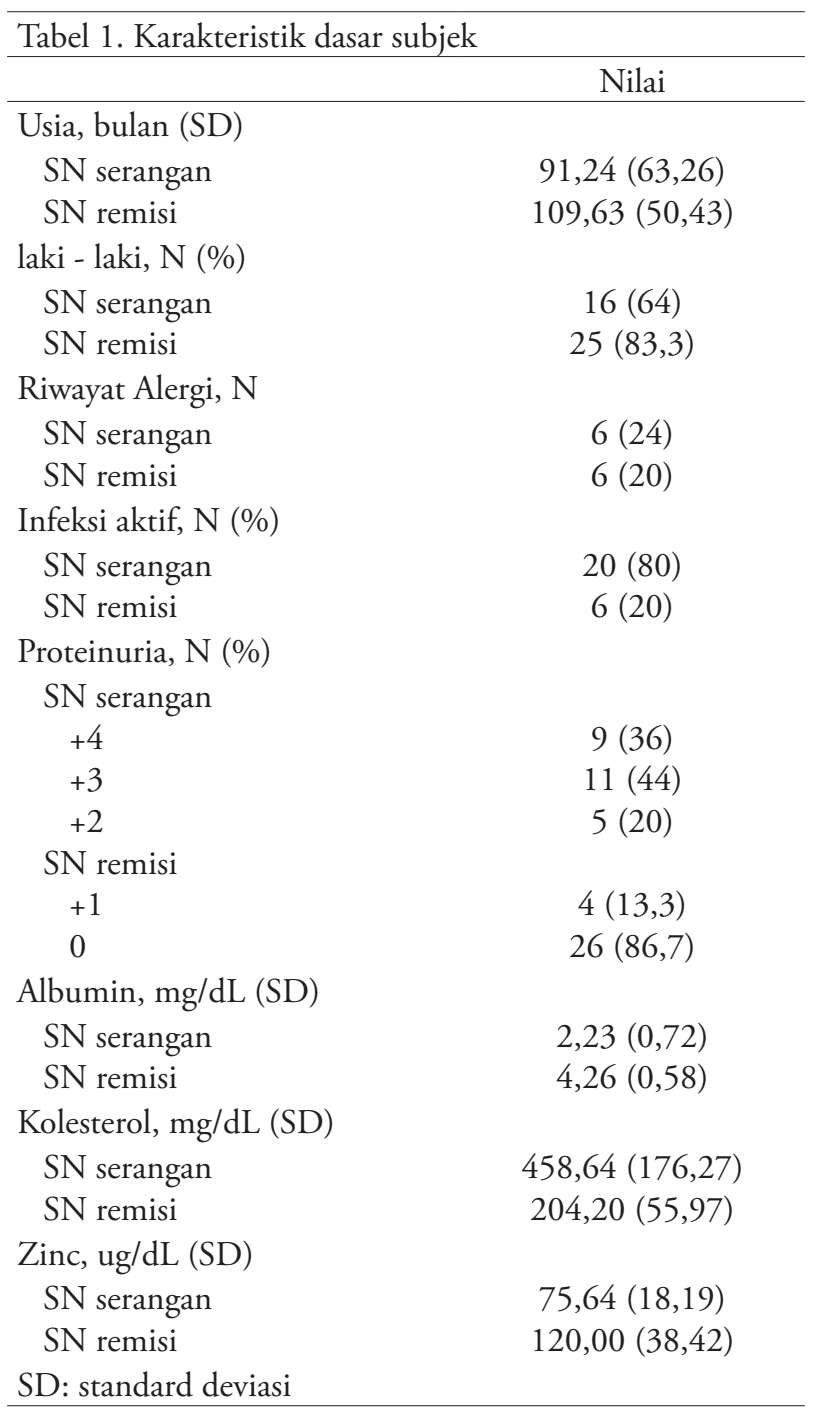

mg/dL. Rerata kadar kolesterol lebih tinggi pada SN saat serangan $(458,64 \pm 176,27 \mathrm{mg} / \mathrm{dL})$, sementara $\mathrm{SN}$ remisi $204,20 \pm 55,97 \mathrm{mg} / \mathrm{dL}$. Rerata kadar zinc SN saat serangan serangan $75,64 \pm 18,19 \mathrm{ug} / \mathrm{dL}$ sedangkan SN saat remisi 120,00 $\pm 38,42 \mathrm{ug} / \mathrm{dL}$. Rerata kadar zinc anak $\mathrm{SN}$ saat serangan dan remisi masih normal (70$150 \mathrm{ug} / \mathrm{dL}$ ).

Analisis memberkian kesan semakin bertambah derajat proteinuria, semakin berkurang rerata kadar zinc. Analisis lebih lanjut secara statistik pada SN serangan terdapat hubungan yang bermakna antara derajat proteinuria dan kadar zinc serum ( $\mathrm{p}=0,044)$.

Kadar albumin serum tidak berkorelasi signifikan dengan kadar zinc serum baik SN serangan $(\mathrm{p}=0,188)$ maupun remisi $(\mathrm{p}=0,193)$. Kadar kolesterol serum tidak berkorelasi dengan kadar zinc serum pada $\mathrm{SN}$ saat serangan $(\mathrm{p}=0,353)$ dan $\mathrm{SN}$ saat remisi $(\mathrm{p}=0,465)$.

\section{Pembahasan}

Sindrom nefrotik pada anak berisiko hypozincemia, terutama saat serangan atau relaps. Albumin yang merupakan transporter utama zinc menurun pada pasien SN. Gangguan kompleks filtrasi glomerulus pada SN menyebabkan kehilangan substansi penting serum, seperti transpor protein, immunoglobulin, dan trace element termasuk zinc. ${ }^{3,14,18}$ Peningkatan kolesterol total pada SN mungkin berhubungan dengan zinc. Penelitian pada hewan coba ditunjukkan bahwa defisiensi zinc menurunkan aktivitas enzim LPL dan LCAT yang berakibat pada peningkatan kebutuhan kolesterol. ${ }^{16,17}$

Penelitian ini mendapatkan rerata kadar zinc serum normal pada $\mathrm{SN}$ saat serangan maupun remisi, yaitu $70-150 \mathrm{ug} / \mathrm{dL}$. Rerata kadar zinc pada SN saat serangan $(75,64 \pm 18,19 \mathrm{ug} / \mathrm{dL})$ lebih rendah dibandingkan dengan SN saat remisi $(120,00 \pm 38,42 \mathrm{ug} / \mathrm{dL})$. Penelitian sebelumnya mendapatkan rerata kadar zinc pada saat relaps untuk SN relaps sering adalah $58,45 \pm 6,29 \mathrm{ug} /$ $\mathrm{dL}$, relaps jarang $61,58 \pm 4,47 \mathrm{ug} / \mathrm{dL}$, dan kontrol anak sehat $89,64 \pm 18,22 \mathrm{ug} / \mathrm{dL}$. Kadar zinc serum anak SN lebih rendah dibandingkan kontrol dan rerata kadar zinc serum pada anak SN di bawah normal. ${ }^{13}$

Defisiensi zinc, dalam meta analisis, berhubungan dengan kerentanan seseorang terhadap infeksi saluran nafas dan suplementasinya pada suatu studi, mengurangi insiden infeksi saluran nafas pada anak pra sekolah, mencegah diare dan mengurangi durasi serta keparahan diare pada anak. ${ }^{4,5}$ Penelitian pada pasien SN ditunjukkan bahwa suplementasi zinc mengurangi risiko infeksi dan menurunkan risiko relaps. ${ }^{8}$ Studi meta analisis menunjukkan bahwa suplementasi zinc mengurangi kejadian infeksi yang memicu relaps pada pasien SN. ${ }^{10}$ Penelitian ini menunjukkan bahwa infeksi aktif didapatkan pada sebagian besar pasien SN saat serangan (80\%) yang secara bermakna lebih tinggi dibandingkan SN saat remisi. Kejadian infeksi merupakan faktor risiko terjadinya relaps pada $\mathrm{SN}$ dengan mayoritas $(72 \%$ - 94,6\%) pasien SN saat relaps memiliki infeksi aktif. ${ }^{6,7}$ Kadar zinc serum yang rendah meningkatkan risiko infeksi yang memicu relaps dan kondisi relaps menurunkan zinc. 
Muhammad Fathah dkk: Hubungan derajat proteinuria, kadar albumin, dan kolesterol serum dengan kadar zinc pada SN

Tabel 2. Hubungan proteinuria dengan kadar zinc serum anak SN

\begin{tabular}{lccc}
\hline Proteinuria & $\mathrm{N}$ & $\begin{array}{c}\text { Median } \\
\text { (minimum }- \text { maksimum) }\end{array}$ & Rerata (SD) \\
\hline SN serangan ${ }^{a}$ & & & \\
$\quad+4$ & 9 & $66(47-87)$ & $65,33(12,84)^{*}$ \\
+3 & 11 & $79,5(47-98)$ & $77,60(15,14)^{*}$ \\
$\quad+2$ & 5 & $76,5(68-127)$ & $87,83(23,13)^{*}$ \\
SN remisi & & & \\
$\quad+1$ & 4 & $108(87-114)$ & $104,25(11,84)$ \\
0 & 26 & $109,5(88-282)$ & $122,42(40,61)$ \\
\hline
\end{tabular}

${ }^{\mathrm{a}}$ Uji Kruskal wallis; * $\mathrm{p}=0,044 ;$ SD: standard deviasi

Tabel 3. Korelasi kadar albumin dan kolesterol serum dengan kadar zinc serum pada anak SN saat serangan dan remisi

\begin{tabular}{|c|c|c|}
\hline & \multicolumn{2}{|c|}{ Kadar zinc serum } \\
\hline & $\mathrm{r}$ & $\mathrm{p}$ \\
\hline \multicolumn{3}{|l|}{ Albumin } \\
\hline Serangan, $\mathrm{n}=25$ & 0,272 & $0,188^{a}$ \\
\hline Remisi, $\mathrm{n}=30$ & 0,193 & $0,307^{\mathrm{a}}$ \\
\hline \multicolumn{3}{|l|}{ Kolesterol } \\
\hline Serangan, $\mathrm{n}=25$ & $-0,194$ & $0,353^{b}$ \\
\hline Remisi, $n=30$ & $-0,139$ & $0,465^{\mathrm{a}}$ \\
\hline
\end{tabular}

Penelitian ini menunjukkan hubungan antara derajat proteinuria dengan konsentrasi zinc serum pada anak $\mathrm{SN}$ saat serangan. Semakin berat derajat proteinuria tampak semakin rendah kadar zinc serum. Penelitian lain menyebutkan terdapat korelasi positif peningkatan ekskresi zinc urin dengan peningkatan proteinuria pada pasien sindrom nefrotik. ${ }^{3}$ Kompleks filtrasi glomerulus yang terganggu pada $\mathrm{SN}$ menyebabkan lolosnya berbagai komponen penting serum, seperti protein, immunoglobulin, trace element, dan termasuk zinc. Protein yang difiltrasi berlebihan menyebabkan reabsobsi tubuler proksimal terganggu dan reabsorsi asam amino dan trace element menurun. ${ }^{3}$

Kadar albumin serum tidak berkorelasi dengan kadar zinc pada anak SN saat serangan maupun remisi pada penelitian ini. Studi menunjukkan kadar albumin serum yang meningkat berkorelasi dengan kadar zinc serum yang meningkat. Penelitian lain menunjukkan terdapat kadar albumin yang secara bermakna lebih rendah saat relaps dengan disertai kadar serum zinc yang lebih rendah. ${ }^{11-13}$ Hasil ini berhubungan dengan fungsi albumin sebagai transporter utama zinc dalam sirkulasi. ${ }^{14}$
Kadar kolesterol pada penelitian ini tidak berkorelasi dengan kadar zinc serum. Penelitian menunjukkan bahwa defisiensi zinc meningkatkan kadar kolesterol total, LDL, trigliserida, dan menurunkan kadar HDL. ${ }^{16,17}$ Studi lain pada pasien hemodialisis ditunjukkan bahwa defisiensi zinc meningkatkan distribusi lipoporotein - kolesterol pada fraksi non - HDL (VLDL, LDL). Asam lemak total plasma cenderung meningkat pada defisiensi zinc. ${ }^{19}$ Studi meta analisis mengungkap bahwa kekurangan zinc memengaruhi aktivitas enzim lipoprotein lipase (LPL) dan lechitin cholesterol acyl transferase (LCAT). Aktivitas kedua enzim tersebut menurun dan kemudian meningkatkan kebutuhan kolesterol. ${ }^{17}$ Hubungan kolesterol dengan kadar zinc tidak ditemukan pada penelitian ini. Studi menunjukkan peningkatan kadar kolesterol pada pasien SN berkorelasi dengan penurunan kadar albumin serum, tetapi belum terdapat penelitian mengenai hubungan kadar zinc serum dan kolesterol serum secara langsung pada anak SN. ${ }^{1,2}$

Penelitian menggunakan subjek yang berbeda pada subjek SN saat serangan dan remisi menyebabkan distribusi data subjek pada beberaapa variabel yang 
diteliti tidak normal. Penelitian ini belum dapat menyingkirkan faktor perancu status infeksi yang mungkin memengaruhi status zinc pasien. Faktor diet pada pasien juga tidak dianalisis lebih lanjut yang sangat berpotensi memengaruhi kadar zinc subjek. Penelitian ini juga tidak dilakukan terhadap jenis $\mathrm{SN}$, jenis pengobatan $\mathrm{SN}$, regimen pengobatan yang diberikan, dan lama pengobatan. Penelitian ini tidak dilakukan penyesuaian terhadap pasien SN saat serangan rawat jalan dan rawat inap. Pasien SN saat serangan yang rawat jalan dapat memiliki kondisi klinis yang jauh lebih baik dibandingkan pasien rawat inap meskipun keduanya dalam kondisi yang sama.

\section{Kesimpulan}

Kadar zinc anak SN saat serangan lebih rendah dibandingkan saat remisi, tetapi keduanya masih dalam batas normal. Derajat proteinuria berhubungan secara bermakna dengan kadar zinc serum pada anak SN saat serangan, tetapi tidak pada $\mathrm{SN}$ saat remisi. Kadar albumin serum tidak berkorelasi dengan kadar zinc serum pada anak SN saat serangan maupun remisi. Kadar kolesterol total serum tidak berkorelasi dengan kadar zinc pada anak SN saat serangan maupun remisi. Perlu penelitian serupa dengan desain uji klinis acak secara kohort prospektif untuk menilai pasien yang sama saat serangan dan remisi. Perlu penelitian yang membandingkan kadar zinc serum antara pasien SN dengan infeksi dan pasien bukan SN dengan infeksi. Perlu penelitian yang membuktikan perbedaan kadar zinc serum pada anak $\mathrm{SN}$ saat serangan kelompok rawat jalan dan rawat inap.

\section{Ucapan terimakasih}

Peneliti mengucapkan terimakasih kepada seluruh subjek penelitian atas partisipasinya, laboratorium GAKY FK UNDIP Semarang atas kerjasama pemeriksaan laboratorium, dan RSUP Dr. Kariadi Semarang yang telah memberikan izin penelitian.

\section{Daftar pustaka}

1. Andolino TP, Adam JR. Nephrotic syndrome. Peds Rev 2015;36:117-26.
2. Noone DG, Lijma K, Parekh R. Idiopathic nephrotic syndrome in children. The Lancet. 2018; 392:61-74.

3. Mumtaz A, Anees M, Fatima S, Ahmed R, Ibrahim M. Serum zinc and copper levels in nephrotic syndrome patients. Pakistan J Med 2011; 27:1173-6.

4. Prasad AS. Zinc is an antioxidant and anti inflammatory agent: its role in human health. Frontiers in Nutrition. 2014;1:1-10.

5. Roth DE, Richard SA, Black RE. Zinc supplementation for the prevention of acute lower respiratory infection in children in developing countries: meta - analysis and meta regression of randomized trial. Int J Epid 2010;39:795-808.

6. Sarker M, Islam M, Saad T, dkk. Risk Factor for relapse in childhood nephrotic syndrome - a hospital based retrospective study. Faridpur Med Coll J 2012;7:18-22.

7. Balaji J, Kumaravel KS, Punitha P, Rameshbabu B. Risk factors for relapse in childhood steroid sensitive nephrotic syndrome. Indian J Child Health 2017;4:322-6.

8. Kumar D, Arya P, Sharma IK, Singh MV. Effect of zinc therapy in remission of pediatric nephrotic syndrome. Int J Cont Ped 2017;4:2036-40.

9. Sherali AR, Moorani KN, Chisty SH, Khan SJ. Zinc supplement in reduction of relapses in children with steroid sensitive nephrotic syndrome. JCPSP 2015;24:110-13.

10. Bhatt GC, Jain S, Das RR. Zinc supplementation as an adjunct to standard therapy in childhood nephrotic syndrome - a systematic review. World J Clin Ped. 2016;5 :383-90.

11. Muryawan MH, Soemantri Ag, Subagio HW, Sekarwana N. Pengaruh suplementasi ekstrak ikan gabus (Channa striata) terhadap kadar albumin, kolesterol, waktu remisi dan kejadian relaps pada anak sindrom nefrotik. Medica Hospitalia 2019;6:7-12.

12. Haque F, Hanif M, Choudhurry TR. Role of zinc in patient with nephrotic syndrome. J Ped Nephrol 2017;5:1-7.

13. Hameed AAM, Abdulraoof JI, Almosawy JMH. Zinc level in children with relapsing nephrotic syndrome. Int J Curr Res 2018;10:1-9.

14. Kambe T, Tsuji T, Hashimoto A, itsumura N. The physiological, biochemical, and molecular roles of zinc transporter in zinc homeostasis and metabolism. Physiol Rev 2015; 95:749-84.

15. Kim M, Chung S, Shin SJ, Chang YS, Koh ES. Relationship between serum zinc concentration and proteinuria in patients with chronic kidney disease. Nephr Dial Transpl 2017;32: 595.

16. Albuquerque FM, Filgueiras MS, Rocha NP, dkk. Association between serum zinc level and hypercholesterolemia and insulin resistance in Brazilian children. Cad Saude Publica 2018;34:1-13.

17. Priyanga R, Wathurapatha WS, Ishara MH, Jayawardana R, Galappatthy P, Constantine GR. Effects of zinc supplementation on serum lipids: a systematic review and meta-analysis. Nutr Metab (Lond) 2015;12:1-16.

18. Roohani. Zinc and its importance for human health: a review. J Res Med Sci 2013;18:144-57.

19. Wang LJ, Wang MQ, Hu R, dkk. Effect of zinc supplementation on maintenance hemodialysis patients: a systemic review and meta-analysis of 15 randomized controlled trials. Biomed Res Int 2017;024769:1-11. 